\title{
COGNITIVE-COMMUNICATIVE ORGANIZATION OF THE EVALUATIVE FRAME
}

\begin{abstract}
Anna Illinichna Prihodko
Prihodko, A.I. Cognitive-communicative organization of the evaluative frame // Lege artis. Language yesterday, today, tomorrow. The Journal of University of SS Cyril and Methodius in Trnava. Warsaw: De Gruyter Open, 2016, vol. I (1), June 2016. - p. 275-308. DOI: 10.1515/lart-2016-0006 ISSN 24538035
\end{abstract}

Abstract: The focal topic of this paper is the discussion of the actualization of the framing script that realizes the evaluative potential. Functional-semantic representation of the frame organization of the certain illocutionary potential is a complex formation in the form of a set of coordinated actions. They determine the communicants' stages of interaction acts for the implementation of the defined aims.

Keywords: frame, functional-semantic representation, evaluation, utterance, interlocutor, interaction, illocutionary, topical, demonstrative, communication.

\section{Introduction}

Participating in acts of communication, we either perceive what is said or produce utterances by ourselves. The perception of acts of communication is a complex process involving the use of a wide range of information. However, analysis of all known methods of expression and transmission of information can be presented, according to van Dijk, in terms of knowledge, having "a more general nature: understanding inevitably based on more general concepts, categories, rules and strategies" (Дейк 1989: 16).

One of the first and by far the most simple structures for the representation of semantic high-level data is, according to Schank, the script (Schank 1982: 456-464; Schank 1990: 9), which is a set of combined time connections of lower level concepts, describing the ordered time sequence of stereotyped events. However, in modern 
linguistics the term "script" is not used. Instead of it, the term "frame" was established. It can be described as the typical structure for the ordering, organization and representation of certain data or information. The starting point for this theory is the fact that the person trying to learn a new situation or to have a new look at common things, selects from his memory some data structure (the way), which is called a frame, in such a way that changing in it some details makes it suitable for the understanding of the broader class of phenomena or processes. A frame "is a data structure for representing a stereotyped situation" (Минский 1981: 7; see also: Касевич 1988: 20; Bara 2010; Langacker 2008).

In recent years, the term "frame" has been widely used in cognitive science (Жаботинская 1999: 14-16; Brockelman 2011; Kroon 1998: 205-223). The term "frame" is used primarily for the characterization of such structures of consciousness, which are formed for displaying situations in object-human cognitive activity. Taking into account this thesis the efficiency of its use in relation to more complex kinds of human speech activity should be recognized because a frame is "an important linguistic component of the cognitive field of text structures, as well as the production, transformation and transposition of knowledge, ideas and thoughts" (Кусько 2001: 212).

The notion "frame" includes the interpretation of the situation as a cognitive category, and as a text element. Fillmore defined a frame as a group of words the union of which is motivated and structured by definite standardized knowledge constructions or constructions that schematize human experience (Филлмор 1988: 54). Frame semantics is a declarative method of knowledge representation, which is formulated in terms of descriptions and is a bundle of knowledge about a particular area of human activity, on the ontology of the world. Such understanding of the frame gives grounds to speak of it as a definitely organized system (set) of propositions, which schematize corresponding denotative situations, that is, as a minimum informative block. 
In other words, the frame can be called the cognitive-communicative field, or communicative frame (Романов 1988: 27; Соколовская 1993: 59-69; Dijk 1998: 137). The evaluative utterance occupies not the last place in the formation of the core of this field. Being a speech act it is aimed at solving specific problems of communication in all its connections and relations, taking into account its functional and semantic properties, and features that fix different aspects of displaying the existing reality in the thinking-speech process by the speaker (Безугла, Романченко 2013: 32-33; Altmann 1990: 12).

As the directed speech act of one of the participants in the communication act, an evaluative utterance reflects the pragmatic nature of the interaction process, thereby serving as a specific indicator of partners' communicative activity. At the same time, as a component of the communicative activity of one of the speakers and thus partly displaying the process of communication in the statement, an evaluative utterance may not reflect fully the entire process of communication, and can only represent a definite single step of participants of this communication, which is aimed at achieving a certain (predetermined) target.

To find out the possibility of the utterance, which realized an evaluative potential, to display substantial characteristics of the act of communication, it is necessary first of all to elucidate where and how an evaluative utterance can reveal its properties as a component of communicative activity. To begin with, we must consider the following utterance in the system of the cognitive-communicative field, communicative frame, which displays a functional purpose of evaluative utterance as well as the organization of the social factors that influence the process of communication.

The aim of this paper is to examine the updating of frame script that implements the evaluative potential. Achieving this goal resulted from the identification of a number of specific objectives: the study of the realization of the structure of evaluative utterances in the frame; the identification of functional-semantic features of this 
realization. The material, which is subjected to analysis, was a selection of approximately 500 utterances of the works by contemporary British and American writers. The criterion of the selection was the presence of evaluative words in the utterance.

Our paper is structured as follows: firstly, we will present the theoretical description of the frame in linguistics in general. Then, we will report briefly on the results of some previous works dealing with analysis of functional-semantic features of the utterances that make up the evaluative frame. Finally, we will provide and comment on our findings, before making some concluding remarks and suggestions for future research.

Methods and techniques are determined by the objectives, the material, the theoretical nature of the article and are of complex character. They integrate theses of the cognitive theory and discourse theory. Speech act analysis is used while studying the pragmatic characteristics of utterances containing evaluative concepts; the framing technique is used to structure the speech act on the example of the evaluative utterance.

\section{Frame as a cognitive cover of the evaluative utterance}

The formation of the frame as the specific structure of consciousness, corresponding to the representation of the event, has an ontological basis. Pankrats emphasizes that it is realized in the course of re-experiencing the same situation or in the monitoring of it. By virtue of the fact that the description of the situation receives similar from the language point of view forms, stereotypical connections are set in the following order: "some situation in the real world - understanding and division of the situation in the consciousness - conventionalization of linguistic forms of description of the situation" (Панкрац 1992: 16).

The logical analysis of concepts, which provides for the establishment of the laws of its internal organization in order to identify its components and modeling their interactions, confirms the notion about the frame as a stereotypical situation 
(Жаботинская 1999: 14; Мартинюк 2011; Степанов 1981: 189). The conceptual analysis of the logical plan is determined by the system of predicates and propositional structures representing the situation in the form of frames.

As far as the person's life-world is made up of many situations, then their language and speech fixation is in need of the adding-up of situations into the utterances. Thus, the evaluative utterance is the product of a certain reflection pattern, scene, and script in the communicative act (Самохіна 2012; Underhill 2011). It combines such basic components as partners, or communicants - sender and the addressee and referent (world fragment of things, or images), which are joined in the act of communication based on the orientation of communicative action, thus creating a single dynamic system - the cognitive-communicative field (Жаботинская 2013: 47-76; Сусов 1979: 95), or a kind of communicative frame, the constituents of which are participants in the act of communication (speaker and, accordingly, the addressee), the content of the utterance (in our case - evaluative), the place where the communication occurs, the relationship between participants at the time of communication (Романов 1988: 28).

Based on the fact that the frame is constituted by combining the situations, evaluative utterances can be presented in this form:

$\mathbf{E F}=\left(\right.$ S.ev. $_{\text {. }}+$ O.ev. $_{\text {. }} \mathbf{P}$ (Sp.ev. + Ad.ev. $)$

$\mathrm{EF}$ - evaluative frame

S.ev - subject of evaluation

$\mathrm{O}_{\text {ev }}-$ object of evaluation

$\mathrm{P}$ - predicate

Sp.ev - speaker

Ad.ev-addressee

Note that the object of evaluation is a variable element, because it can refer to both animate and inanimate objects, as well as the whole situation. 
Components of the frame can be characterized by various parameters, depending on the conditions of social interaction between the partners. Thus, the target orientation of an utterance always involves some forms of communicative and social influence personal, public, official, unofficial. The relationship between the partners is also conditioned by the social status and role in determining the positions of the participants of a communicative interaction act in order to fulfil certain social roles: the seller - the buyer, the ticket-collector - the passenger, the chief - the subordinate, etc. (and also the initiator - the recipient and vice versa) (Kroon 1998: 216-217).

In accordance with socio-role status, the relationships between participants of communication are spread mainly in the social sphere of communication, where social role reflects interactional conditions between the subject of communicative action and its object. According to some linguists, the conditions of social interaction between communicants are based on three types of relations - equality, subordination and dominance (Benthem 1991: 17-36), which are implemented in the familiar, unconstrained, neutral and elevated communication (speech) registers. Communicative role as a kind of invariant unit of behavior, is located in the general scheme of activities and is related to relevant normative expectations, which may be shown by the communicants in a given communicative and particular social situations.

Communicants' socio-role status is based on a specific set of rights and obligations of the participants in the act of communication, their awareness of these rights and obligations (Романов 1988: 29-30). Social situation and the socio-role status of partners form pragmatic factors that are the integral part of the frame organization of utterances in general and the evaluative one in particular, and they require their registration in the implementation of the act of communication (Шахнарович 1998: 59; Kintsch 1988: 163-182). These factors or parameters of interaction in the evaluative utterance may be called constant constituents of the frame. 
The relations between the communicants, conditioned by their socio-role status, are marked by certain linguistic means signalling the interlocutor about his partner's status. Moreover, some linguists (Голубничая 1994: 13-15; Шеловских 1995: 6-7) consider that the choice of language means in a particular type of interaction in the implementation of the same communicative intention to some extent depends on the relationship between the interlocutors and their socio-role status. Every act of communication is characterized by the definite form of interaction, which is based on its correlation with the situation-type, which is the frame with the features and functional conditions inherent to it (Дейк 1989: 26-30; Касевич 1988: 20-24; Минский 1988: 289). Frame structure can be regarded as an independent configuration consisting of a core, a set of standard forms of speech acts, and participants of a speech event. In addition to these components, an important role belongs to the objective, plan and consequent.

Thus, the evaluative situation can be attributed to the frame, as it includes evaluation of the phenomena of the outer world and illustrates the continuity of images of the object and the subject, objectified in the system parts of speech, as well as all the constituents of utterances that make up the situation (Жаботинская 1999: 15-16; Приходько 2016: 70-71).

Graphically hyperframe, which represents the potential of evaluation, can be presented in the form of the following scheme (see Fig. 1): 


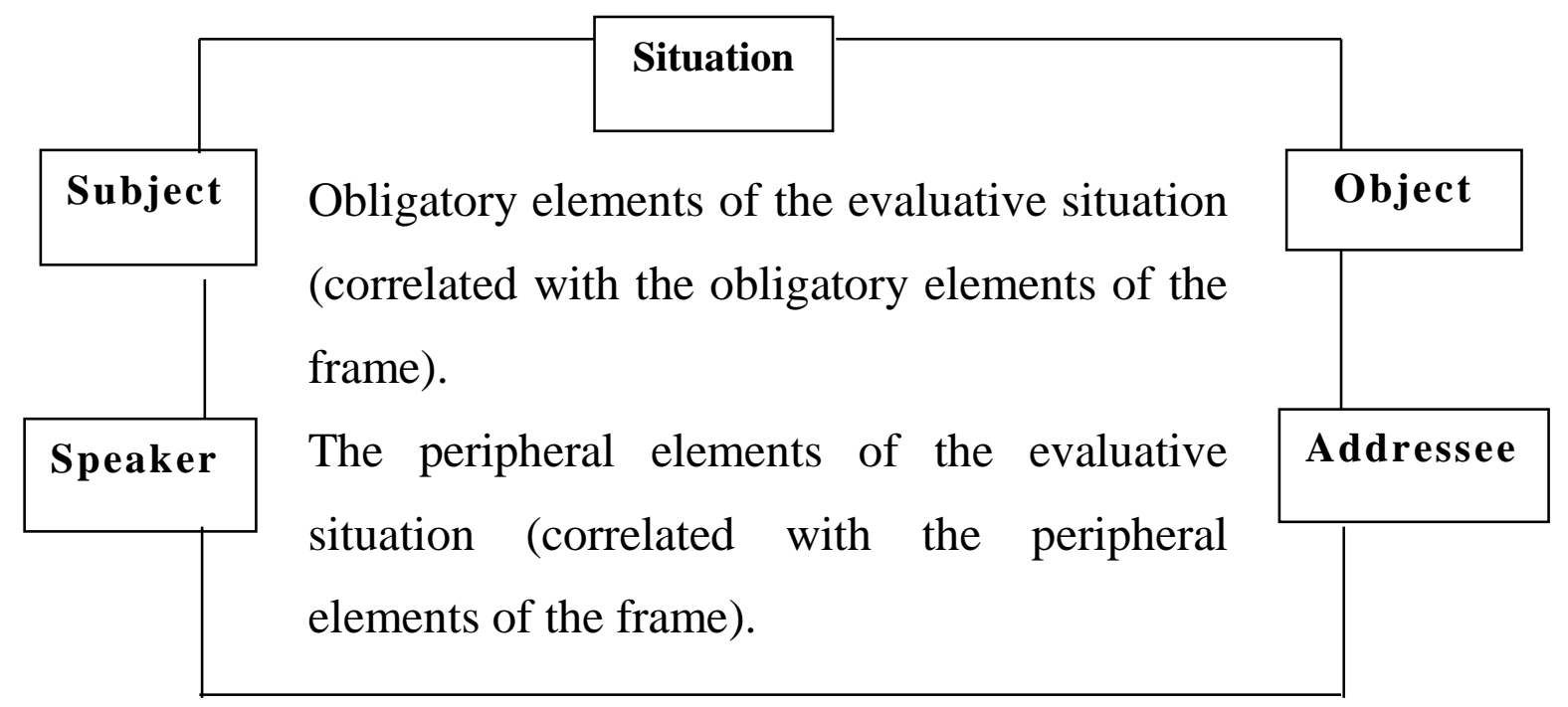

Figure 1. Structure elements of the evaluative hyperframe

Considering the above stated, the cognitive-communicative field of evaluative situation can be represented as a hyperframe of verbal interaction, which displays all components of the frame in their interconnection and interdependence that allows the determination of the sequence of the constituents of data in the process of updating and predetermine the appearance of certain actions that characterize the core of the frame structure in functional and semantic aspects.

\section{Actualization of evaluation in the cognitive-communicative field}

We have considered those items that are included into the cognitive-communicative field (communicative frame). This allows us to analyse in detail the process of updating the frame structure of evaluative utterances that make up the situation.

By actualization, we understand the use of the certain linguistic unit with the purpose of information transmission in a particular communicative situation, when actualized notion, represented by certain information is identified with its real representation in the speaker's mind (Бакиева 1998: 6-7; Anderson 2011). In the process of updating the peculiar conversion of a language unit into a signal is observed (Арнольд 1990: 28), so that the verbal expression used by the speaker is correlated with a standard form of the communicative act, presenting the proper characterization of the image that 
Pocheptsov (Почепцов 1986: 10) and Shakhnarovich (Шахнарович 1986: 53) call "hyperconfiguration".

The speaker produces the utterance and uses language as the tool of impact. Communicative and functional purpose of such utterance is determined by its intended use (communicative intension, illocutionary focus) from the speaker's side - in this case, the author, for the planned impact on the partner - the reader, e.g.: "They plonked you out there in the mud ... and your job was to get killed if the enemy attacked. You were not allowed to retreat; you knew that nobody would be allowed to succour or reinforce you; ... A very pleasant prospect. A most jolly look out" (R. Aldington "Death of a Hero", p. 54).

Here the author describes the hopeless situation of the heroes. Note also that the communicative intention determines not only the role of the speaker as a direct participant in the act of interaction, but also indicates the specific purpose of the speech work and the method of its presentation: whether the speaker expresses a statement or a question, an order or a request by his action.

The aim may be considered as an indication of the regulation of verbal behaviour in terms of the target impact of the utterance, introducing it as a social event of verbal interaction implemented by the utterance or utterances. The purpose of actualization of the utterance expects "the listener's evaluative perception" (Волошинов 1931: 69). In this example, (1) a negative assessment of the situation at war that runs throughout the utterance is highlighted in the last two sentences, where a striking contrast between what is said and what is meant is ironically shown.

It can be assumed that in the evaluative utterance the speaker accents or highlights exactly what he thinks is relevant at the moment. It is carried out directly by the speaker-subject by using words, phrases or sentences. 
Recognition of what is meant by the speaker is connected with the act of the target (illocutionary) use of linguistic expressions, the object of which is actualized in a speech act proposition with an appropriate communicative task in the system of communicative hyperframe. In this case, the speaker's reference determines the semantic reference by means of attaching to the utterance in the structure of the frame and can be assessed by interlocutors as right or wrong, appropriate or inappropriate to the situation of the analyzed frame (Арутюнова 1990: 411), e.g.: "I was standing way the hell up on top of Thompson Hill, right next to this crazy cannon that was in the revolutionary War and all" (D. Salinger "The Catcher in the Rye", p. 28).

The hero of the novel is a teenager, who uses harsh words in his speech. He was angry at everything and everyone. In his phrase, adjective crazy stands next to hell, and is perceived as the norm of his emotional and expressive manner to represent his attitude to the surrounding reality, that is, this adjective performs a reference function.

The connection of the reference correlation of speech product and its target installation in the act of communication is typical of the process of updating of the frame structure of the latter (in this case, utterances expressing evaluation), here it serves as a functional-semantic representation of the act of communication (Кубрякова 1996: 160-165; Kearns 2014). Actualized by the speaker, it appears as a multidimensional formation, which shows the act of the binding of the reference propositional content of the utterance to the target act at the time of communication.

This idea can also be applied to those evaluative utterances forming a frame. In this case, this presentation includes several levels:

1) illocutionary;

2) topical;

3) demonstrative (structural or lexico-syntactical).

The level of social interaction comes out separately. It is the ground where the 
interaction of these levels takes place and the process of updating of utterances in a frame occurs. All these levels show how the union of the three sides of the utterance pragmatics, semantics and syntax is reflected in the act of communication. It also reveals the connection between the selected levels of the utterance in the act of communication, which, however, retain their autonomy, and that becomes apparent on closer examination of each of them individually.

\section{Functional-semantic representation of evaluation in the structure of the utterance}

The illocutionary level dominates over the other levels, and is based on the thematic content (communicative or "holistic" sense) (Бахтин 1986) of the utterance and its linguistic form of expression. This allows the relations between the levels to be marked, using semantic or formal-grammatical means present therein.

Purposeful verbal action with the corresponding illocutionary characteristic in its detailed (frame) form is a functional-semantic representation of the utterance in which the illocutionary component, divided into illocutionary potential and illocutionary force (energy) (Серль 1986: 153; Austin 1994: 87), gives the possibility to establish a way of implementation of the intention in the speech act.

As a way of realization of communicative intention, illocution is not only a property of any individual use of utterance. It is bilateral: illocutionary potential acts as a functional or pragmatic rule that opens and guides the communicants' actions within a given frame structure, thus creating a typical illocutionary frame for a certain type of interaction (Дейк 1989: 26-30). The particular correlation of action with a communicative purpose in this frame constitutes the illocutionary force, or the purpose of such action.

Within the functional-semantic representation of a typical structure of illocutionary frame it is possible to combine multiple actions with a different degree of expression of illocutionary force, but one of them is dominant. In this case, the illocutionary force 
with regard to other illocutionary manifestations of the combined complex is superior, e.g.: "After a particularly deafening morning, Larry erupted from his room and said he could not be expected to work if the villa was going to be racked to its foundations every five minutes. Leslie, aggrieved, said that he had to practice, Larry said it didn't sound like practice, but more like the Indian Mutiny" (G. Durrell "My Family and Other Animals", p. 19).

Evaluation in this humorous statement is one of its components designed to implement several communication goals: Larry insists that it is impossible to work in such conditions, but Leslie tries to convince him that it is possible. The effectiveness of the evaluative utterance depends on the degree of the speaker's influence on the addressee and lies in the illocutionary force of the utterance. In this case, the illocutionary force of persuasion is the dominant one. Due to this, the perlocutionary effect is achieved that does not meet the speaker's intentions, which are expressed in Larry's utterance.

The unit of illocutionary level of functional-semantic representation is the illocutionary act-event marked by illocutionary force (Романов 1988: 41). In this sense the illocutionary force of the act-event belongs to the pragmatic and communicative meaning of the speech formation, in which, according to Vagner, "the strategic plan of the speaker" is realized (Vagner 1977: 137).

It should be noted that there exists a set of indicators of the implementation of the illocutionary force of the speech product. This fact gives grounds to consider the variability of functional means of expression of illocutionary force (modal verbs, particles, introductory words and constructions, etc.) as a regulator of relations between illocutionary force and illocutionary potential in particular, as well as between the speaker's global strategy, leading to a positive result, and the communicative purpose of such formation as a whole, e.g.: "Lord Balcairn, said Lord Metroland, "will you kindly leave my house immediately?"..."Oh, yes, I am going to", said Simon."You didn't 
think I was going to go back to the party like this, did you?" (E. Waugh "Vile Bodies", p. 103).

Such structures as will/would you represent a request. Sometimes they are used in the function of invitation (offer), thus forming the speech act of request or invitation. As far as their grammatical and lexical design, it practically does not differ from the formulas inherent in the request. The communicative purpose of this utterance - to humiliate, to put out the door of his house - is achieved by a number of means: the beginning of the sentence is constructed in accordance with the tact maxim, observing the principle of politeness. Explicitly this utterance is a polite request (a marker is the lexeme kindly, the semantic structure of which contains semes of positive evaluation), implicitly it is a rough order. Here we observe violation of discourse strategy, there is a dissonance between locution and perlocution: the goal of the utterance contradicts the linguistic means of its registration.

Analysis of the frame structure, the process of the communicative act, and the communicants' social status also help to decode this utterance adequately: the scene of action - the London mansion of a noble aristocrat. The status of a man of the world and the role of the host do not allow him to use rude expressions, though he has every reason to expel the person convicted of wrongful deeds from his house.

Therefore, in the case described, all illocutionary complex is divided into separate intentional units, that is independent illocutionary acts-events: beginning with the rough command up to the promise not to return to the house. The formula of politeness is used here rather euphemistically, as a means of softening the true communicative intention, to give the utterance a sarcastic tone.

In order to achieve the communicative purpose in acts-events introductive structures with the words of the corresponding semantics are used. For example, for the realization of inducement the verb of impelling semantics is used: "Permit me to make 
a suggestion. Go to America. I'm afraid Europe will make you unhappy" (I. Shaw "Lucy Crown", p. 20).

The negative tone of the statement is emphasized by the adjective unhappy, with the negative prefix un-, which is considered a common means of representation of the negative meaning.

To express polite request the verb of interrogative semantics is used: "Just let me ask you one question ... Even now could you put that enormous thing into the back of a car?" (R. Dahl "Twenty-Nine Kisses from Roald Dahl", p. 56).

Thus, the illocutionary level of functional-semantic representation of an evaluation utterance, implemented in the form of the act-event reflects the nature of the partners' speech behaviour at a particular moment of communication.

As a unit of the planned cooperation program realization, the illocutionary act-event determines the interlocutors' contribution into realization of such goal at a certain moment, revealing the degree of interlocutors' responsiveness and marking any of their actions: corrective initiating, responsive, etc. The illocutionary level of functionalsemantic representation determines the course of communicants' specific actions in the evaluative utterance, creating its frame-based outlines.

\section{Intentional potential of evaluative utterances}

The topical level of functional-semantic representation of the structure of the utterances of evaluative frame is related to the content of the communicants' intentional actions joined together by theme, or rather by its framing organization in the process of communication. The notion "topical level" of functional-semantic representation of the evaluative utterance is not identical to the notion of "topical part", which reflects the actual division of the speech formations. It correlates with the communicative meaning of the speech formation as an integral unit, and on this basis, is regarded as one of the 
organizing factors of communication, e.g.: "He got out of the cab in a state of wary anger - with himself for not having seen Irene" (J. Galsworthy "In Chancery", p. 97).

The communicative meaning of the utterance in the example above is characteristic of Soames as during the action, and as a person in general. Such information is represented by the oxymoron phrase wary anger, expressing a complex range of emotions. The adjective wary and noun anger belong to the same semantic field of feelings. It brings them together. But wary contains the seme of "peace", and anger the seme of "excitement". Consequently, they contradict each other, and thereby contribute to reveal Soames's nature. Caution is his constant characteristic, and anger is a variable. Both characteristics are in conflict. Such an emotional state is not peculiar to Soames, and thereby a tragicomic effect is achieved.

Being a factor in the organization of verbal interaction of certain illocutionary type and showing, in fact, pragmatic knowledge, as well as the interlocutors' social communicative competence, the theme of functional-semantic representation is in definite relations with the illocutionary potential of the whole utterance - it is subjected to the latter. It is necessary to mention that there are situations of indirect expression of the illocutionary indicator. In this case, the theme, being the integral part of the organization of communication, can show the concrete illocutionary force of this or that participant of the utterance.

Understanding of the topical level as a semantic unity, as "a holistic sense" is connected with the interpretation of the theme in the works of Bakhtin and Voloshinov, in which the difference between "sense of the whole utterance, its topic" (Бахтин 1986: 255, 301-303) and "meaning of the utterance" (Волошинов 1931: 65-87) is observed. The theme of the speech formation is in fact individual and unique, as well as the utterance itself. It is an expression of the situation that gives rise to the generation of the utterance acquiring relative completeness under certain conditions within the framework of a certain author's plan, i.e. intention. 
This plan is a subjective point of the utterance and it is inseparably combined with the objective part - "subject-semantic aspect, limiting the latter by linking it to a specific (single) situation of speech communication, with all individual circumstances of it, with personal participants, with their previous speeches - utterances" (Бахтин 1986: 256), e.g.: "Up Broadway he turned and halted at a glittering café, where are gathered together nightly the choicest products of the grape, the silkworm, and the protoplasm" (O.Henry "The Cop and the Anthem", p. 40). And here is one more example: "He betrayed the fact, that the minutest coin and himself were strangers" (O.Henry "The Cop and the Anthem", p. 40).

These utterances are interesting from the standpoint of contrast semes. In the first utterance, we observe the availability of quality, in the second - the lack (or the least amount of it), which is represented by phrases the choicest products and the minutest coin, in which there is no difference between traditional and situational signifier. But they contain a tautological repetition of elative. The adjectives minute and choice contain elative semes without a morphologic fixator. Fixing them with the morpheme, the author reinforces the expressive and evaluative connotation.

Café collected the best foods, clothing and people, the choicest of the choice, but the poor man Soap has no money in his pockets. Comparing these two contrasting facts, the recipient accepts a feeling of bitter irony as for the unjust order of the world: all for the rich and nothing for the poor. This is the topic of the analysed speech formations.

Inside the theme of the utterance, there is a meaning that is all those moments of the utterance, which are identical to themselves for all repetitions. It must be noted that this meaning is an integral component of the utterance. The case is different with the topic of the particular speech formation, which depends on the situation where it is used. Here it will have a different topic, i.e. each time it will acquire "a new act of binding to the content at the moment of its use" (Романов 1988: 45), e.g.: "It catered to large appetites and modest purses. Its crockery and atmosphere were thick; its soup 
and napery thin. Into this place Soapy took his accusive shoes and telltale trousers without challenge" (O.Henry "The Cop and the Anthem", p. 40).

Soap's appearance is miserable, eloquent and ludicrous. Comic-ironic effect is built on cohesion, which is meant as the appearance of equivalent elements in equivalent positions, performing an identical function (to show Soap's miserable state). These identical elements are large appetites and modest purses, its crockery and atmosphere were thick, its soup and napery thin.

Cohesion is built on antonymous relations. Adjectives thick, thin are actualized both in the direct and figurative meaning, simultaneously combining positive and negative evaluative connotation: thick crockery, thin napery present positive evaluation, thick atmosphere, and thin soup express negative evaluation. Convergence techniques are complemented by epithets accusive shoes and telltale trousers.

So, we can conclude that the theme of functional-semantic representation of the utterance in particular and illocutionary frame of a certain type of interaction in general as a complex dynamic system of signs "is always concrete and determined not only by its linguistic forms, sounds, intonation, but also by verbal moments of speech situation" (Волошинов 1931: 66-67), that is, the content of the constituents of frame configuration of utterance.

The unit of the topical level of functional-semantic representation of the illocutionary frame is a proposition, actualized by the speaker in a particular speech context. The term "proposition" is quite common in the scientific literature - in logics and epistemology, where it is used synonymously with the term "judgment" (Ивин 1999), and accordingly - in the school of logical analysis of language (Арутюнова 1999), in cognitive science (Кубрякова 1996) and in computer models of knowledge among researchers of artificial intelligence and psychology. However, in all these branches of science the notion of proposition derives its specific definition, and its own 
interpretation, which, however, is reduced either to the statement of the true state of things, or to the internal coherence of the utterance.

In a broad sense, the proposition is understood as "a statement expressed by the sentence" (Степанов 1995: 68), as a generalized formula including the core of the semantic structure together with its aspectual, modal and temporal characteristics (Никитин 1988: 120), that is, as a "semantic invariant, common to all members of the modal and communicative paradigm of sentences" (Кочерган 1999: 113). This approach reflects not only the nominative but also the communicative aspect of the utterance.

In the context of cognitive-semantic understanding the proposition appears as a sentence at the pre-communicative level with irrelevant functional-communicative characteristics, and therefore it is perceived as an abstract model of the extra-linguistic situation, as the objective content of the utterance, and as "the result of abstraction from the variety of periphrastic forms" (Вендлер 1986: 273). A proposition in this sense is a cognitive reflection of the situation in the human's mind, a stable semantic core with the "a-modal essence" (Панкрац 1992: 10), which is not directly related to the modus of its existence in the person's head. The proposition can act as separate formations, as it manifests itself in performative formulas (Романов 1988: 46): e.g., "I shall never be aware of my own wit till I break my shins against it" (E. Lear "Topsy-Turvy World", p. 205); "Would you be an awful dear and let me use that as a pillow?" (Modern English Short Stories, p. 64); or act as hyperproposition the common part of several propositions, which, depending on the different illocutionary and perlocutionary forces can be neutralized in the context: "It's a chance in a thousand, and I think it would be madness not to take it" (S. Maugham "Theatre", p. 45).

As the topical level is functionally subordinated to the illocutionary one, then the actualized proposition is always part of the illocutionary function or force. In this case, a topical proposition is understood as a configuration of lexical items, interrelated by 
semantic and syntactic relationships into a single meaningful unit, which is the nomination of any fact or any situation, taking into account all actualized moments (speaker's views, time, actual division): "No, I will not be late," - said Walter unhappily and guiltily certain that he would be. Her voice annoyed him. It drawled a little, it was too refined - even misery" (A. Huxley "Point Counter Point", p. 154)

Guilt and irritation are two feelings, which possess Walter's soul differently. Where the author hears the excitement and plea, Walter notices a peculiar irritating sound of the voice. The lexeme refined (elegant, cultured, polished) which is used with the adverb too acquires a negative connotation, which is almost everywhere accompanied Walter's words when he is speaking about Marjory.

Using the notion of a proposition as the unit of the topical level of functional-semantic representation of illocutionary frame, we should bear in mind the lexically determined proposition with semantic positions that are already filled with specific lexical units. The selection of specific lexical nomens for semantic positions is carried out at the presyntactical stage of creation of the speech formation and is determined by the speaker in the act of communion: what he offers to consider communicatively important at a particular point of communication, taking into account the expressed intentions (illocutionary force) and speech situation (Бондарко 1999: 8; Toolan 2013). In the proposed form, the proposition is the functional-semantic representation, which creates the substantial core of the illocutionary frame and acts as a semantic invariant for a certain set of semantically related speech formations (utterances) and their nominalizations.

A proposition in the functional-semantic representation is the actualized proposition, which is a combination of a propositional form, and specifiers and actualizers selected by the speaker. The actualized proposition is a sort of base of interlocutors' communication program, which is set by illocutionary variable, e.g.: "I've been doing 
some homework", Eleonor said. "On Mr Russel Wrenn Hazen. I looked in Who's Who. Caroline brought home a whale last night" (I. Shaw "Bread upon the Waters", p. 53).

In the example above the noun whale realizes figurative meaning "a person or a thing impressive in size or quality", emphasizing Hazen's greatness. It is the proposition of the given utterance. It is obvious that the figurative meaning is insufficient and additional information about Hazen is needed, e.g.: "What do you mean whale?" "A big one", said Eleanor. "He's the head man of one of the largest law firms in Wall Street, founded by his father, now dead. He's on the boards of about a dozen giant corporations, starting with oil and going down to agrobusiness and chemicals, he's trustee of his old school, he has one of the biggest collections of Impressionalist and modern art in America" (I. Shaw "Bread upon the Waters", p. 53).

This context proves Hazen's greatness, which is the propositional content of this fragment. Attention is focused on the component big in synonymous large and giant. The adjectives big and large are used in the superlative degree, i.e. the grammatical factor "works" creating the intensification of the quality. Giant is a metaphor, which is implemented on the background of the abovementioned adjectives as their intensification: giant means of extraordinary size. In this case, we can talk about hyperproposition (complicated proposition), because there is a common part of the propositions of both utterances (Кочерган 1999: 114) (representation of Hazen's greatness), which reflects the deep structure of the situation, taken in the aspect of "its internal logical structure" (Касевич 1988: 58).

Here we also see the link to the topical level lies with illocutionary and demonstrative levels of the functional-semantic representation (Романов 1988: 46), when any of the parts of the utterance (in this case the evaluative one) is related to the topical content of the illocutionary frame and marked by certain means of speech. 
The connection of the demonstrative with topical and illocutionary level is complex. It is marked by multifaceted manifestations and requires special consideration. Here we only note that the process of language realization of communicative (illocutionarytopical) content of the utterance, the choice of surface-syntactic roles (subject, predicate, the secondary members of the sentence) and morphological expression of the predicate by the specific part of speech (a word form or a whole word combination) is determined to a large extent by the illocutionary purposefulness of such utterance with reliance on propositional specifiers or actualizers.

The role of propositional specifiers (actualizers), which are a kind of link between the illocutionary, topical and demonstrative levels, is quite important in the communicative process in general, and in the process of realization of the evaluative illocutionary frame in particular (Müller 2012). The use of language units in a concrete illocutionary frame is an actualization of relevant level units (illocutionary evaluative act-event actualized proposition - corresponding demonstrative form) in the functional-semantic representation of the typical illocutionary frame.

To illustrate the above mentioned statement let us consider the following example: "It was some time before Adam could get attended to. "I've nothing but some very old clothes and some books", he said. But here he showed himself deficient in tact, for the MAN's casual air disappeared in a flash. "Books, eh?" he said." And what sort of books, may I ask?" "Look for yourself." "Thank you, that's what I mean to do. Books, indeed" (E. Waugh "Vile Bodies", p. 23).

In this indirect evaluative utterance, interaction of presupposition and proposition (directive possessiveness) form the inner content. Its function is a mockery of the passenger. To understand this, it is necessary to turn to the text situation. The analysed utterance belongs to the clerk conducting the customs examination. After analysing the role relationships and communicants' status, it is not difficult to understand that he is the master of the situation. He does not need the owner's permission to inspect his 
luggage. Words of gratitude (thank you) are a manifestation of emphasized neglect that brings a shade of irony into communication.

The role of propositional actualizers acting as connecting elements between the units of the corresponding levels in terms of the formation of frame organization of evaluative utterance, their importance in the definition of the topic and, ultimately, and illocutionary function, it can be shown by the example of the temporal actualizers in the propositional (topical) content of the utterance when the potential of a particular illocutionary speech act determines the format for the topical content of the utterance. In our example, the actualizers are expressions: "some time before" (sends us to precontext), "What sort of books, may I ask?" (describes the situation at the moment of speaking) and, finally, "thank you, that's what I mean to do" (sends us to post-context).

Thus, the topical level of functional-semantic representation of the structure of the evaluative utterance presented in the form of the actualized proposition is the basis for building a program of partners' communication in the illocutionary evaluative frame, which reflects the content and interlocutors' links in terms of their flashback, prospection and present moment, i.e. the time of use of a certain part of the utterance in a typical frame configuration.

\section{Demonstrative representation of the illocutionary potential of evaluative utterances}

The final level of functional-semantic representation of the structure of the utterance in the evaluative frame is a demonstrative one. It is understood as the grammatical representation of a particular speech formation according to the language rules in all its constructive variants and forms. As the demonstrative level is determined by illocutionary and topical levels, it is necessary to accept the fact that the illocutionary nature of intentional action can be labelled with a variety of syntactic constructions or models which can define all the modifications, convergence and contrast, combining into more complex structural formations. 
The main invariant of grammatical representation of the frame organization of typical interaction is a standard performative formula in the form of the following configuration: 1 person - verb in the present tense form - ( 2 person $)$ - the object / purpose, where the last symbols can represent as separate sentences and the infinitive groups or infinitives (Романов 1988: 48).

Performative formula is the most appropriate means of expressing the illocutionary potential of the act of communication, as it points to the correspondence between illocutionary function of this or that part of the utterance and the purpose of the utterance as a whole in a definite frame. This relationship is marked by performative marks, which include the performative verbs and adverbs (Austin 1994: 27). It should be noted that the evaluative utterances include not only performative verbs, but also any others that may be used in all tenses and moods.

The demonstrative variety of formulas used in the evaluative frames shows that it is one and the same structure, which is given in different forms. This possibility of the formal varying of nomination of the illocutionary potential shows that it possesses a certain set of syntactic means of expressing its intentional nature, which can be represented as a specific inventory of possible structural forms that maintain the frame organization of the utterance (in this case the evaluative one). Below there are some examples: "I'm making the most utterfool of myself" (A. Christie "The Secret of Chimneys", p. 125). "Father Rothschild was conspiring with Mr. Outrage and Lord Metroland. He stopped short in the middle of his sentence. "Forgive me," he said, "but there are spies everywhere. That man with the beard, do you know him?" "Exactly", said Mr. Outrage. "I think it would be better if we continued our conversation in private." They withdrew to Lord Metroland's study" (E. Waugh "Vile Bodies", p. 97). "He was very poor, and must have seen fabulously rich to him and very wasteful. He could live for a fortnight on what she spent in an evening" (R. Aldington "Short Stories", p. 96). 
These utterances show that for the expression of evaluation different lexical and grammatical means are used: the superlative degree of comparison of adjective the most utterfool; etiquette formula forgive me and expression it would be better, pointing to an ironic tone, and thereby to the interlocutors' disdainful attitude to the subject under discussion.

In many illocutionary frames we do not find explicit means of expression of the intentional verbal influence (threat, pride, joy, boasting). However, we observe means of prosody (Sökeland 1980; Nuyts 2014: 53-76) or specific syntax scheme-models of the speech formation with a specific topical content, which are used as the illocutionary indicators. This topical content at the moment of the speech influence reveals the conditions for the implementation of such content, taking into account anticipated response actions in order to formulate and specify further the nature of the purpose of the proposed utterance, e.g.: "The snowflake of Dolly's face held its shape; for once she did not dissolve" (T. Capote "The Grass Harp", p. 33).

To create a metaphorical image in this utterance, two meanings of the noun snowflake: direct - the snowflake held its shape and figurative the snowflake of Dolly's face are actualized. The verb dissolve is connected with the pronoun she by direct syntactic relationship and realizes figurative meaning, but at the same time its indirect syntactic relationship with snowflake and implementation of the direct meaning is obviously seen.

The following example also deserves consideration: "I'd love it", said Miss Matfield, forcing a smile" (J.B. Priestly "Angel Pavement", p. 180). Miss Mayfieldэs sincere desire in does not correspond to her speech behaviour, that is the real intention of one of the communicants (in this case, Miss Mayfield) is conveyed by non-verbal means (forcing a smile). 


\section{Conclusion}

The formal indicators of realization of the illocutionary potential in the evaluative frame define its functional specificity, being to some extent a means of marking of communicants' actions in the process of communication. They may be either basic, for example, standard performative formula, or transposed when one of the grammatical forms (construction or formator) is used in its unusual function. Quite often for this purpose non-verbal, paralinguistic means of communication are used.

An important component of the mechanism of the formation of the evaluative utterance is a cognitive factor. On the one hand, it helps to conceptualize the relations between situations of extralinguistic reality (sender's perspective), and on the other hand, it serves as a specific signal for the process of the mental perception of text (recipient's perspective). Thus, participants of interaction use are general schemes of encoding and decoding of information that is contained in the utterance.

Consequently, the actualized structure of the evaluative utterance is connected with the realization of the frame structure of a typical act of communication in the form of a holistic multi-level formation - functional-semantic representation, including illocutionary, topical and demonstrative levels of presentation. Actualization of a frame structure takes place on the background of social interaction, where the functionalsemantic representation of the evaluative frame is promoted by implementing in its structure such items as the illocutionary act-event, topical proposition and typical grammatical construction. As a result, there is a picture of interconnected and interdependent in their development concepts - from parts of the utterance - to all evaluative utterance, which is the core of the cognitive-communicative field of interaction. 


\section{References}

Altmann, G.T.M. (1990). Cognitive models of speech processing: An introduction. In Cognitive models of speech processing: psycholinguistic and computational perspectives. Cambridge: Cambridge Univ. Press, p. 1-23.

Aldington, R. (1968). Death of a hero. Leningrad: Sphere.

Aldington, R. (1967). Short stories. Moscow: Progress Publishers.

Anderson, J.M. (2011). Linguistic representation (Trends in linguistics: Studies and monographs). Berlin: Mouton de Gruyter.

Arnold, I.V. / Арнольд И.В. (1990). Стилистика современного английского языка. Москва: Просвещение.

Arutyunova, N.D. / Арутюнова Н.Д. (1990). Референция. In Лингвистический энциклопедический словарь. Москва: Советская энциклопедия, с. 411-412.

Austin, J.L. (1994). How to do things with words. Stuttgart: Philipp Reclam.

Bakhtin, М.М. / Бахтин М.М. (1986). Эстетика словесного творчества. Москва: Искусство.

Bakieva, G.F. / Бакиева Г.Ф. (1998). Фрейм и моделирование ситуации. In Доклады VI Международной конференции "Семантика языковых единий". Москва: СпортАкадемПресс, 1, с. 6-7.

Bara, B.G. (2010). Cognitive pragmatics: The mental processes of communication. USA: MIT Press.

Benthem, J.V. (1991). Linguistic universals in logical semantics. In Semantic universals and universal semantics. Berlin: Max Niemayer, p. 17-36.

Bezugla, L.R. \& Romanchenko, O.I. / Безугла Л.P., Романченко I.O. (2013). Лінгвопрагматика дискримінації у публічистичному дискурсі. Харків: ФОП Лисенко І.Б.

Bondarko, A.V. / Бондарко А.В. (1999). Основы функциональной грамматики: Языковая интерпретация идеи времени. Санкт-Петербург: Изд-во СанктПетербургского. ун-та.

Brockelman, T.P. (2011). The frame and the mirror: On collage and the postmodern. Evanston: Northwestern University Press. 
Capote,T. (1974). The grass harp. Moscow: Progress Publishers.

Christie, A. (1986). The secret of chimneys. New York: Dodd, Mead.

Concise dictionary of cognitive terms / Краткий словарь когнитивных терминов. (1996). Koubriakova, E.S. (ed.) / Кубрякова Е.С. (гл. ред.). Москва: МГУ.

Dahl, R. (1969). Twenty-nine kisses from Roald Dahl. London: Michael Joseph.

Dijk, T.A. van. (1998). Discourse as interaction in society. In Discourse as interaction. Discourse studies: a multidisciplinary approach. Thousand Oaks, New Delhi: Sage, 2, p. 1-37.

Dijk, T.A. van. / Дейк Т.А. ван. (1989). Язык. Познание. Коммуникаиия. Москва: Прогресс.

Durrell, G. (1987). My family and other animals. Москва: Высшая школа.

Galsworthy, J. (1975). In chancery. Moscow: Progress Publishers.

Golubnichaya, O.I. / Голубничая О.И. (1994). Семантико-функииональные особенности высказываний, направленных на поддержку адресата / Автореф. дис... канд. филол. наук / Киевский государственный лингвистический университет. 10.02.04 - германские языки. Киев.

Fillmore, Ch. / Филлмор Ч. (1988). Фреймы и семантика понимания. In Новое 8 зарубежной лингвистике. Когнитивные аспекты языка, 23. Москва: Прогресс, c. 52-92.

Huxley, A. (1967). Point counter point. New York: Penguin Books.

Kasevich, V.В. / Касевич В.Б. (1988). Семантика. Синтаксис. Морфология. Москва: Наука.

Kearns, K. (2011). Semantics. New York: Palgrave Macmillan.

Kintsch, W. (1988). The role of knowledge in discourse comprehension: a construction-integration model. In Psychological review, 5, p. 163-182.

Kochergan, М.Р. / Кочерган М.П. (1999). Загальне мовознавство. Київ: ВЦ "Академія".

Kroon, C.A. (1998). Framework for the description of Latin discourse markers. In Journal of pragmatics, 30, p. 205-223. 
Kusko, К.Үа. / Кусько К.Я. (2001). Фреймові стратегії у різножанровому іноземномовному дискурсі. In Мовні і концептуальні картини світу, 5. Київ: Київський національний ун-т ім. Т. Шевченка, с. 210-214.

Langacker, R.W. (2008). Cognitive grammar: A basic introduction. New York: Oxford University Press.

Lear, E. (1964). Topsy-turvy world. Moscow: Foreign Language Publishing House.

Martunyuk, A.P. / Мартинюк А.П. (2011). Словник основних термінів когнітивнодискурсивної лінгвістики. Харків: ХНУ ім. В.Н. Каразіна.

Maugham, W.S. (1977). Theatre. New York: Arno Press.

Minsky, M. / Минский M. (1988). Остроумие и логика когнитивного бессознательного. In Новое в зарубежной лингвистике. Когнитивные аспекты языка. Москва: Прогресс, 23, с. 281-309.

Minsky, М. / Минский М. (1981). Фреймы для представления знаний. Москва: Энергия.

Modern English short stories. (1978). Moscow: Progress Publishers.

Müller, B. (2012). Determiners and quantifiers - differences. Munich: GRIN Verlag. Nuyts, J. (2014). Notions of (inter)subjectivity. Intersubjectivity and intersubjectification in grammar and discourse. In Theoretical and descriptive advances, p. 53-76.

Nikitin, M.V. / Никитин М.В. (1988). Основы лингвистической теории значения. Москва: Высшая школа.

O.Henry (1977). The cop and the anthem. Moscow: Progress Publishers.

Pankrats, Yu.G. / Панкрац Ю.Г. (1992). Пропозициональные структуры и их роль в формировании языковых единии разных уровней (на материале сложноструктурированных глаголов современного английского языка) / Автореф. дис...д-ра филол. наук / Институт языкознания РАН. 10.02 .04 германские языки. Москва.

Pocheptsov G.G. / Почепцов Г.Г. (1986). О комуникативной типологии адресата In Речевые акты в лингвистике и методике. Пятигорск: Государственный педагогический институт иностранных языков, с. 10-17. 
Priestley, J.B. (1974). Angel pavement. Moscow: Progress Publishers.

Prihodko, A.I. / Приходько A.I. (2016). Категорія оцінки в контексті зміни лінгвістичних парадигм. Запоріжжя: ЗНУ.

Romanov, A.A. / Романов А.A. (1988). Системный анализ регулятивных средств диалогического общения. Москва: ИЯ АН СССР .

Salinger, D. (1998). The catcher in the rye. Moscow: Apt + N.

Samohina, V.O. / Самохіна B.O. (2012). Жарт у сучасному комунікативному просторі Великої Британї̈ та США. [2-е вид перероб. і доп.]. Харків: ХНУ імені В.Н. Каразіна.

Searle, J.R. / Серль Дж.P. (1986). Что такое речевой акт? In Новое в зарубежной лингвистике. Москва: Прогресс, 17, с. 151-169.

Schank, R.C. (1982). Reminding and memory organization: an introduction to MOPs. In Strategies for natural language processing, p. 455-493.

Schank, R.C. (1990). Tell me a story: A new look at real and artificial memory. New York: Scibner.

Shahnarovich, A.M. \& Golod, V.I. / Шахнарович А.М., Голод В.И. (1986). Когнитивные и коммуникативные аспекты речевой деятельности. In Bonpocbl языкознания, 2, с. 52-56.

Shahnarovich, A.M. / Шахнарович A.M. (1998). Онтогенез мыслеречедеятельности: семантика и текст. In Филологические науки, 1, с. 56-64. Shaw, I. (1982). Bread upon the waters. New York: Delacorte Press.

Shaw, I. (1984). Lucy crown. London: New English Libr.

Shelovskih, Т.I. / Шеловских Т.И. (1995). Речевой акт совета: функииональнопрагматический анализ / Автореф. дис... канд. филол. наук / Воронежский государственный университет. 10.02.19 / - теория языка. Воронеж.

Sökeland, W. (1980). Inderektheit von sprechandlungen: Eine linguistische untersuchung. Tübungen: Niemeyer.

Sokolovskaya, K.A. / Соколовская К.А. (1993). Прагматическая интерпретация аспектуальной характеристики высказывания. In Вопросы языкознания, 5, с. 5969. 
Stepanov, Yu.S. / Степанов Ю.С. (1995). Альтернативный мир, Дискурс, Факт и принцип Причинности. In Язык и наука концуа 20 века. Москва: Институт языкознания РАН, с. 35-73.

Stepanov, Yu.S. / Степанов Ю.С. (1981). Имена, предикаты, предложения (Семиологическая грамматика). Москва: Наука.

Susov, I.P. / Сусов И.П. (1979). О двух путях исследования содержания текста In Значение и смысл речевых образований. Калинин: Калининский государственный ун-т, с. 90-103.

Toolan, M. (2013). Narrative: A critical linguistic introduction. London; New York: Routledge.

Underhill, J. W. (2011). Creating worldviews: metaphor, ideology and language. Edinburgh: EUP.

Vagner, K.R. (1977). Sprachstrategie - illokutien versus. Sprachakt illokution. In Deutsche Sprache, 5, S. 126-140.

Vendler, Z. / Вендлер 3. (1986). Причинные отношения. In Новое в зарубежной лингвистике. Москва: Прогресс, 18, с. 264-276.

Voloshinov, V.N. / Волошинов В.Н. (1931). Конструкция высказывания. In Литературная учеба, 3, с. 65-87.

Waugh, E. (1977). Vile bodies. Boston: Little Brown.

Zhabotynska, S.A. / Жаботинская C.A. (1999). Концептуальный анализ: типы фреймов. In Вісник Черкаського університету: Серія. "Філологічні. науки", 11, с. $12-25$.

Zhabotynska, S.A. / Жаботинская С.А. (2013). Имя как текст: концептуальная сеть лексического значения (анализ имени эмоции). Cognition, communication, discourse, 6, c. 47-76. Available at:

https://sites.google.com/site/cognitiondiscourse/vypusk-no6-2013/zabotinskaa-s-a 


\begin{tabular}{|l|l|l|}
\hline \multicolumn{1}{|c|}{ Contact data } & \multicolumn{1}{c|}{$\begin{array}{c}\text { Fields of interest } \\
\text { Anna Illinichna Prihodko, } \\
\text { Pragmatics, cognitive } \\
\text { linguistics, concept } \\
\text { Professor at the Chair of } \\
\text { English Philology. } \\
\text { Zaporizhzhya National } \\
\text { University. Zhukovsky str., } \\
\text { 66, Zaporizhzhya, Ukraine, } \\
\text { 69600 } \\
\text { e-mail: } \\
\text { anna.prikhodko.55@mail.ru }\end{array}$} & \\
\hline
\end{tabular}

\section{Résumé in English}

The focal topic of this paper is the discussion of the actualization of the framing script that realizes the evaluative potential. Functional-semantic representation of the frame organization of the certain illocutionary potential is a complex formation in the form of a set of coordinated actions. They determine the communicants' stages of interaction acts for the implementation of the defined aims. Functional conditions for the realization of the functional-semantic representation of the typical illocutionary potential are stages on the interlocutors' way to the intended result within a specific type of interaction, which are characterized by a specific set of interactive actions inherent for a particular illocutionary potential (frame). Frame structure can be regarded as an independent configuration consisting of a core, a set of standard forms of speech acts, and participants of speech event. In addition to these components, an important role belongs to the objective, plan and consequent. The evaluative situation can be attributed to the frame, as it includes evaluation of the phenomena of the outer world and illustrates the continuity of images of the object and the subject, objectified in the system parts of speech, as well as all the constituents of utterances that make up the situation. Actualization of the evaluative utterance on the background of the implementation of the illocutionary potential's conditions is connected with the typical frame organization of an act of communication, which forms the functional-semantic representation with the corresponding levels: illocutionary, topical, and demonstrative. 
Keywords: frame, functional-semantic representation, evaluation, utterance, interlocutor, interaction, illocutionary, topical, demonstrative, communication.

\section{Résumé in German}

Das Hauptthema des Artikels ist die Untersuchung der Aktualisierung des FramingSkripts, welches das evaluative Potential erkennt. Die funktional-semantische Repräsentation der Framing-Struktur des bestimmten Illokutivpotentials ist eine komplizierte Gestaltung in Form einer Reihe von koordinierten Aktionen, in denen die Phasenakte der Kommunikanten-Interaktion in der Verwirklichung der geplanten Ziele festgelegt sind. Die Funktionsbedingungen für die Verwirklichung der funktionalsemantischen Repräsentation des typischen Illokutivpotentials sind Meilensteine auf dem Förderungsweg von Gesprächspartners zum geplanten Ergebnis im Rahmen einer bestimmten Interaktionsart, für die der angegebene Satz von den für das bestimmte Illokutivpotential (Frame) charakteristischen Interaktivaktionen bezeichnend ist. Vor dem Hintergrund der Verwirklichungsbedingungen des Illokutivpotentials ist die Aktualisierung der evaluativen Äußerungen mit der typischen Framing-Struktur der Kommunikationsart eng verbunden, diese Framing-Struktur bildet eine funktionalsemantische Repräsentation mit den entsprechenden Ebenen: illokutiven, thematischen, demonstrativen.

Stichwörter: Frame, funktional-semantische Repräsentation, Bewertung, Äußerung, Gesprächspartner, Interaktion, illokutiv, thematisch, demonstrativ, Kommunikation.

\section{Résumé in French}

L'étude d' actualisation de scénario de frame qui réalise la potentialité d'appréciation est le thème central de cet article. La présentation sémantico-fonctionnelle de l'organisation de la potentialité illocutoire se représente comme formation de complexe des actions concertées où les actes d' interaction des communiquants sur réalisation des objectifs fixés sont posés. Les conditions fonctionnelles de la réalisation de présentation sémantico-fonctionnelle de la potentialité illocutoire 
typique sont les jalons orientés vers un avancement des interlocuteurs au résultat dans le cadre d' interaction typique qui a un ensemble des actions interactives spécifiques à la potentialité illocutoire concrete (frame). L'actualisation de l'énoncé dans le cadre des conditions de la réalisation de potentialité illocutoire est liée à l'organisation typique de frame de l' acte de communication. Cet organisation forme la présentation sémantico-fonctionnelle avec les niveaux correspondants : illocutoire, thématique, manifestatif.

Mots-clés: frame, présentation sémantico-fonctionnelle, appréciation, énoncé, locutaire, interaction, illocutoire, thématique, manifestatif, communication

\section{Résumé in Russian}

Центральной темой статьи является изучение актуализации фреймового сценария, реализующего оценочный потенциал. Функциональносемантическое представление фреймовой организации определенного иллокутивного потенциала представляет собой сложное образование в виде комплекса скоординированных действий, в которых задаются этапные акты взаимодействия коммуникантов по реализации поставленных целей. Функциональные условия реализации функционально-семантического представления типового иллокутивного потенциала - это вехи на пути продвижения партнеров общения к намеченному результату в рамках определенного типа взаимодействия, которому присущ заданный набор характерных для конкретного иллокутивного потенциала (фрейма) интерактивных действий. Актуализация оценочного высказывания на фоне условий реализации иллокутивного потенциала связана с типовой фреймовой организацией акта общения, которая образует функционально-семантическое представление с соответствующими уровнями: иллокутивным, тематическим, манифестационным. 
Ключевые слова: фрейм, функционально-семантическое представление, оценка, высказывание, собеседник, интеракция, иллокутивный, тематический, манифестационный, коммуникация.

Article was received by the editorial board 15.07.16;

Reviewed 8.08.16 and 9.08.16.

Similarity Index $2 \%$. 